Studia i materiały z dziedzictwa kulturowego Torunia i regionu, t. 1: STARE I NOWE DZIEDZICTWO TORUNIA,

Toruń 2013

http://dx.doi.org/10.12775/SiMzDzKTiR_T1.2013.016

Franciszek Skibiński

(IZIK UMK, TORUŃ)

\title{
Rzeźba kamienna w Toruniu ok. 1580-1650. Pomiędzy produkcją miejscową a importem z czołowych ośrodków rzeźbiarskich Rzeczpospolitej
}

W literaturze dotyczącej sztuki w nowożytnym Toruniu problematyka rzeźby kamiennej pojawia się zazwyczaj na marginesie rozważań o jej innych aspektach ${ }^{1}$. W konsekwencji wiedza o niej jest ograniczona, zaś część istotnych zabytków pozostaje nieobecna w naukowej dyskusji. Jedynie dzieła najbardziej monumentalne, takie jak pomniki Anny Wazówny i braci Tylickich, doczekały się bardziej szczegółowej analizy, choć nawet tu wiele pytań nadal pozostaje bez odpowiedzi².

Niniejszy przyczynek nie stanowi oczywiście próby wyczerpującego omówienia tak złożonego zagadnienia. Jego celem jest zwrócenie uwagi na kilka pomijanych dotąd obiektów, a także uzupełnienie wiedzy o dziełach lepiej znanych, lecz czasem mylnie opisywanych i interpretowanych. Analizie zostanie poddana zarówno formalna, jak i techniczna strona poszczególnych zabytków, szczególnie w kontekście ich pochodzenia. Rozważania o zachowanych dziełach uzupełnione będą wynikami kwerendy archiwalnej, która objęła również nie w pełni dotąd wykorzystane źródła rękopiśmienne i drukowane. Wszystko to ma na celu podjęcie próby udzielenia odpowiedzi na pytanie, czy nowożytny Toruń był samodzielnym ośrodkiem produkcji rzeźby kamiennej i kamieniarki, czy też był on raczej zależny od importu z zewnątrz, co pozwoli bardziej precyzyjnie określić pozycję miasta na artystycznej mapie Rzeczypospolitej „srebrnego wieku”.

Wyjaśnienia wymaga zastosowana terminologia, odnosząca się do rzeźby kamiennej i kamieniarki, a także profesji rzeźbiarza (w źródłach niemieckojęzycznych „Bildhauer”)

1 Np. w podstawowych syntezach dziejów sztuki w Toruniu: Gwido CHMARZYŃSKI, Sztuka w Toruniu. Zarys dziejów, [w:] Dzieje Torunia, red. K. TYMIENIECKI, Toruń 1933, s. 469-544; Katarzyna KLUCZWAJD, Jacek TYLICKI, Sztuka nowożytna, [w:] Dzieje sztuki Torunia, Toruń 2009, s. 187-364.

2 Patrz m.in. Alicja SAAR-KOZŁOWSKA, Geneza fundacji pomnika grobowego Anny Wazówny w kościele NM Panny w Toruniu, [w:] Sztuka Torunia i Ziemi Chetmińskiej 1233-1815. Materiały konferencji - Toruń 18-20 IV 1983, red. J. POKLEWSKI, Warszawa, Poznań 1986, s. 159-179 oraz Przemysław KRZYSZTOFIAK, Nagrobek braci Tylickich - problem rekonstrukcji i zagadnienia atrybucyjne, [w:] Dzieje i skarby kościoła Mariackiego w Toruniu. Materiały konferencji - Toruń 14-16 IV 2005, red. K. KLUCZWAJD, Toruń 2005, s. 345-356. 
i kamieniarza („Steinhauer”). Historyczne znaczenie tych terminów pozostaje niejasne. Z jednej strony, w źródłach pisanych z terenu dawnych Prus Królewskich - przede wszystkim gdańskich - dostrzegalna jest tendencja do różnicowania pomiędzy rzeźbiarzami i kamieniarzami. Dla przykładu, w aktach gdańskiego cechu murarzy, kamieniarzy i rzeźbiarzy widoczny jest wyraźny - choć nie zawsze konsekwentny - podział na reprezentantów obydwu profesji ${ }^{3}$. Świadczą też o tym dokumenty dotyczące sporu pomiędzy Willemem van den Blocke, mistrzem należącym do wspomnianego cechu, a kilkoma innymi członkami tej organizacji, zwłaszcza Willemem van der Meer zw. Barth. W suplice skierowanej do Rady Miasta Gdańska w 1590 roku van den Blocke wskazał zarówno na zbieżności, jak i różnice istniejące pomiędzy tymi profesjami, pisząc m.in.:

chociaż oni sami siebie nazywaja rzeźbiarzami [...] a właściwie oni zwa się kamieniarzami, $i$ ich praca to rąbanie kamieni, bo oni nie zdobyli zawodu rzeźbiarza ${ }^{4}$.

Z drugiej jednak strony rzemieślnicy, określani jako „kamieniarze”, pracowali również jako rzeźbiarze, wykonując w kamieniu np. detal architektoniczny z dekoracją ornamentalną bądź nawet figuralną, co wynika m.in. z cytowanej supliki mistrza Willema. Wobec braku możliwości precyzyjnego rozróżnienia pomiędzy tymi pokrewnymi profesjami, niniejszy tekst będzie dotyczyć zarówno rzeźbiarzy, jak i kamieniarzy, a terminy te - choć jest to niewątpliwie uproszczeniem - będą stosowane wymiennie.

Studia nad sztuką w nowożytnym Toruniu są znacznie utrudnione przez zniszczenie zgromadzonych w archiwum miejskim dokumentów podczas pożaru ratusza Starego Miasta w 1703 roku. Utracone wtedy źródła dostarczyłyby zapewne wielu informacji o czynnych w mieście rzeźbiarzach i kamieniarzach. Wprawdzie informacje o nich pojawiają się sporadycznie w istniejących dokumentach - np. wpis dotyczący rzeźbiarza Hansa Friedricha, który w 1601 roku zawarł ślub w kościele Mariackim - jednak szczątkowy stan zachowania uniemożliwia ustalenie ich liczby oraz pozycji zawodowej ${ }^{5}$.

Wobec braku źródeł pisanych, podstawowym źródłem muszą stać się zachowane dzieła sztuki ${ }^{6}$. Analiza najwcześniejszych z nich pozwala wysunąć hipotezę, iż w ostatniej ćwierci XVI wieku przez jakiś czas czynny był w Toruniu przynajmniej jeden warsztat rzeźbiarsko

3 Np. w księgach rachunkowych cechu; Akta cechów gdańskich, Archiwum Państwowe w Gdańsku, sygnatury 300, C/2057-2059. Patrz też: Franciszek SKIBIŃSKI, Warsztat Willema van den Blocke w świetle akt gdańskiego cechu murarzy, kamieniarzy i rzeźbiarzy, „Biuletyn Historii Sztuki”, t. 72, nr 1-2, 2010, s. 85-92.

4 Supliki artystów, Archiwum Państwowe w Gdańsku, 36/65, s. 29-32; publikowane w: Franciszek KRZYSIAK, Supliki Hansa Kramera $i$ Willema van den Blocke do Rady Miejskiej w Gdańsku, „Porta Aurea”, t. 6, 1999, s. 72-76 (powyższe tłumaczenie w większości wg tej publikacji). Patrz też: Exzerpte zur Geschichte der Danziger Gewerke, August Bertling, Danziger Künstler, Biblioteka Gdańska PAN, Ms. 2490 (s. nlb.), gdzie wypis z zaginionej skargi na Willema van den Blocke.

5 Liber Copulatorum 1600-1755, Parafia Wniebowzięcia Najświętszej Marii Panny w Toruniu, Archiwum Akt Dawnych Diecezji Toruńskiej, AD 001, s. 4 (publikowane w: Bartłomiej ŁYCZAK, Uwagi na temat siedemnastowiecznych fundacji ołtarzowych w kościele pw. św. Jana Chrzciciela i św. Jana Ewangelisty w Toruniu, „Zapiski Historyczne", t. 77, z. 1, 2012, s. 69, przypis 25).

6 Odnośnie do dzieła sztuki jako źródła historycznego patrz np. Piotr SKUBISZEWSKI, Dzieło sztuki a źródło historyczne, [w:] Proces historyczny w literaturze i sztuce. Materiały konferencji - maj 1965, red. M. JANION, A. PIORUNOWA, Warszawa 1965, s. 277-307. 
-kamieniarski. Tej kierowanej przez nieznanego mistrza pracowni przypisuję tu dwa dzieła, mianowicie epitafium Caspara Frisiusa $(† 1586)$ w kościele św. Jana Chrzciciela i św. Jana Ewangelisty oraz płaskorzeźbę ukazującą zaczerpniętą z dzieła Tytusa Liwiusza historię rzymskiego bohatera Marka Kurcjusza ${ }^{7}$ (il. 1, 2). Pochodzenie i pierwotna funkcja tego drugiego obiektu pozostają nieznane.

Obydwa dzieła wykonano z szarego piaskowca gotlandzkiego, następnie polichromowanego. Na ich pochodzenie $\mathrm{z}$ jednego warsztatu wskazuje daleko idące podobieństwo w opracowaniu scen figuralnych. W obydwu płaskorzeźbach iluzja przestrzeni została oddana bardzo prostymi środkami artystycznymi. Na płaskie tło zostały niejako nałożone umieszczone na jednym planie figury, w większości opracowane w stosunkowo wysokim reliefie. Łączy je daleko idące podobieństwo, widoczne np. w fizjonomiach rzymskiego bohatera oraz klęczącego żołnierza w scenie Zmartwychwstania, o trójkątnym profilu z wysuniętym nosem oraz cofniętą brodą i czołem, a także wyrazistymi, kręconymi wąsami. Jeszcze większe zbieżności dostrzegalne są $\mathrm{w}$ anatomii i proporcjach stojących postaci oraz $\mathrm{w}$ ich antykizujących strojach. Dotyczą one m. in. sposobu przedstawienia nóg, bioder i wydatnych brzuchów, jak również detali ubioru, takich jak rękawy tunik rzymskich żołnierzy.

Twórca tych dzieł pozostaje nieznany. Autorka dokumentacji konserwatorskiej płaskorzeźby przedstawiającej Marka Kurcjusza wiązała ją ze wspomnianym już Willemem van der Meer, czynnym w Gdańsku przez wiele lat mistrzem pochodzącym z flandryjskiej Gandawy ${ }^{8}$. Przy dzisiejszym stanie wiedzy o jego oeuvre atrybucja ta, oparta na mało prawdopodobnych hipotezach, jest jednak trudna do przyjęcia. Według autorki dokumentacji, płaskorzeźba miała pochodzić z Domu Eskenów, gdzie stanowiła jakoby element zachowanego do dziś portalu, na co jednak brak dowodów. Sam portal został hipotetycznie przypisany Willemowi van der Meer przez Lecha Krzyżanowskiego w jego niepublikowanej dysertacji z 1966 roku9 . Jednakże atrybucja ta, wysunięta zresztą z dużą ostrożnością, nie znalazła jak dotąd potwierdzenia ani w innych dziełach mistrza, ani w źródłach pisanych.

Zdumienie budzi szczególnie pojawiająca się w dokumentacji informacja, jakoby w toruńskiej płaskorzeźbie obecny był „typ kompozycji, układ form występujący w wielu jego sygnowanych pracach”; w istocie nie znamy żadnej pracy niewątpliwie przezeń sygnowanej. W literaturze przedmiotu wysunięto jedynie dwie propozycje identyfikacji sygnatury mi-

7 Za zwrócenie mojej uwagi na to drugie dzieło chciałbym podziękować Pani Katarzynie Kluczwajd z Muzeum Okręgowego w Toruniu, za dalsze informacje zaś Panu Emanuelowi Okoniowi z Muzeum Okręgowego w Toruniu oraz Pani Marii Rudy z Instytutu Zabytkoznawstwa i Konserwatorstwa UMK. Wiedza o tym zabytku pozwala mi zrewidować wysuniętą wcześniej hipotezę o braku na terenie miasta dzieł, które można związać z warsztatem odpowiedzialnym za wykonanie epitafium Frisiusa. Obiekt, obecnie zaginiony, znajdował się w zbiorach Muzeum Okręgowego w Toruniu, zaś głównym źródłem wiedzy na jego temat jest dokumentacja konserwatorska, patrz:A. ANGIELSKA, Dokumentacja opisowo fotograficzna. Płycina XVII-wieczna z Muzeum Okręgowego w Toruniu, konserwację wykonano w Zakładzie Konserwacji Elementów i Detali Architektonicznych Instytutu Zabytkoznawstwa i Konserwatorstwa UMK, [mps], Toruń 1977-1978 (s. nlb.), Muzeum Okręgowe w Toruniu, nr inw. S/670/MT (również archiwum Zakładu Konserwacji Elementów i Detali Architektonicznych UMK).

8 ANGIELSKA 1977-1978. Najpełniej o Willemie van der Meer: Jacek TYLICKI, Meer, van der, czyli Barth, [w:] Słownik Biograficzny Pomorza Nadwiślańskiego, red. Z. H. NOWAK, Gdańsk 1997, t. 3, s. 180-185.

9 Lech KRZYŻANOWSKI, Gdańska monumentalna rzeźba kamienna lat 1517-1628, [mps], Warszawa 1966, s. 103-104, Biblioteka Instytutu Historii Sztuki UAM. 
strza, odnoszące się do portali tzw. Domu Eskenów w Toruniu oraz domu przy ul. Długiej 55 w Gdańsku (obecnie przy dworze św. Jerzego tamże). ${ }^{10} \mathrm{~W}$ obydwu przypadkach hipoteza ta nie wydaje się jednak prawdopodobna. Nie wydaje się, by eksponowane litery, ujęte wieńcami trzymanymi przez putta umieszczone w przyłuczach, mogły być sygnaturą rzemieślnika; są one zapewne inicjałami właścicieli domów. Ponadto w Toruniu jedna $\mathrm{z}$ liter została błędnie odczytana (powinno być „FE”-zapewne Franz Esken-zamiast „FB”). Jedynym źródłowo potwierdzonym, zachowanym dziełem rzeźbiarskim warsztatu Willem van der Meer jest kominek w Letniej Sali Rady Ratusza Głównego Miasta w Gdańsku, który $\mathrm{z}$ racji swej formy (m.in. brak płaskorzeźb figuralnych) nie może w tym wypadku służyć za materiał porównawczy.

Hipoteza o niderlandzkiej genezie obydwu dzieł anonimowego warsztatu czynnego w Toruniu może być jednak trafna ${ }^{11}$. Kompozycja sceny Zmartwychwstania w epitafium Frisiusa oraz sposób ujęcia jej poszczególnych elementów znajdują liczne analogie w ówczesnej plastyce niderlandzkiej, choć nie są typowe wyłącznie dla niej. Przykładem może być ukazująca tę samą scenę płaskorzeźba w nagrobku księcia meklemburskiego Krzysztofa w Schwerinie, wykonana w latach dziewięćdziesiątych XVI wieku przez pochodzącego z Mechelen Roberta Coppensa; szczególnie bliskie wydaje się tu opracowanie figury zmartwychwstałego Chrystusa (il. 3).

W dość surowej strukturze architektonicznej oraz dekoracji epitafium Frisiusa na pierwszy rzut oka brak elementów typowych dla niderlandzkiej plastyki późnego XVI wieku, choć np. dekoracja przyłuczy mogła być inspirowana rycinami według Jana Vredemana de Vries $^{12}$. Pomimo tego, mogła być ona dziełem niderlandzkiego kamieniarza, stosującego jednak odmienny modus stylowy, oparty na oszczędnym języku form architektonicznych pozbawionych bogatej dekoracji ornamentalnej. Przykładem tego rodzaju rozwiązań stosowanych przez niderlandzkich emigrantów czynnych w regionie Morza Bałtyckiego jest np. wykonany w latach sześćdziesiątych XVI wieku detal architektoniczny zamku w Vadstenie w Szwecji, wiązany z pochodzącym z Brabancji Pierre'em de la Roche ${ }^{13}$. Z epitafium Frisiusa łączy go wyraźna zależność od modelu porządków architektonicznych rozpropagowanego przez Sebastiana Serlia, leżącego u genezy tego języka form ${ }^{14}$. W przypadku struktury architektonicznej epitafium Frisiusa jedynym poważniejszym odejściem od tego kanonu jest zastosowanie trójdzielnego architrawu, nietypowego dla porządku doryckiego. Projektodawca

10 TYLICKI 1997, s. 184.

11 Niderlandyzujący charakter epitafium podkreśla Jerzy DOMASŁOWSKI, Wyposażenie, [w:] Bazylika katedralna św. Janów w Toruniu, red. M. BISKUP, Toruń 2003, s. 173.

12 Np. F.W.H. Hollstein's Dutch \& Flemish Engravings, Etchings and Woodcuts, ca. 1450-1700, vol. XLVIII, Hans Vredeman de Vries, I, compiled by P. FUHRING, Rotterdam 1997, s. 69-87, nr 51-71.

13 Patrz m.in.: Torbjörn Fulton, Byggnadsskulpturen, [w:] Renässansens konst („Signums Svenska Konsthistoria” 5), av Göran Alm, Lund 1996, s. 122-127.

14 Szerzej na ten temat m.in.: Uwe ALBRECHT, Renaissance-Architektur des westlichen Ostseeraumes im Spiegel von Traktaten und Musterbuch. Kalmar, Kronborg, Frederiksborg, [w:] The Problem of the Classical Ideal in the Art and Architecture of the Countries around the Baltic Sea. Conference - Tallin 9-10 XI 2001, eds. Krista KODRES, Piret LINDPERE, Eva NÄRIPEA, Tallin 2003, s. 13-31. 
sięgnął tu zapewne do modeli prezentujących inne porządki architektoniczne, również wielokrotnie reprodukowane na kartach ksiąg Serlia. Tezę o niderlandzkiej genezie epitafium może też potwierdzać trójbarwna polichromia, imitująca typowy dla tamtejszej małej architektury czarno-czerwono-biały schemat barwny ${ }^{15}$. Również użyty materiał, typowy dla warsztatów czynnych w ośrodkach położonych wzdłuż wybrzeży Bałtyku, wyraźnie wskazuje na północne afiliacje twórcy epitafium.

Ostateczne rozstrzygnięcie kwestii pochodzenia nieznanego mistrza nie jest jednak w tej chwili możliwe, zwłaszcza, że w ostatniej ćwierci XVI wieku w Prusach - przede wszystkim w Gdańsku - obok Niderlandczyków czynni byli także kamieniarze i rzeźbiarze pochodzący z innych części Europy ${ }^{16}$. Mogli oni stosować miejscowy materiał, odwołując się jednocześnie do form znanych im z kraju pochodzenia. Wśród nich warto zwrócić uwagę na stosunkowo licznych przybyszów z Saksonii oraz pobliskiego Śląską, gdzie dzieła o nieco zbliżonym charakterze wykonywali w drugiej połowie XVI wieku m.in. członkowie rodziny Walther (np. epitafium zmarłego w $1581 \mathrm{r}$. Heinricha von Hermsdorf w saskim Neustadt) ${ }^{17}$.

Dziełem innego warsztatu jest natomiast powstałe w tym samym czasie epitafium, upamiętniające Andreasa Gretscha, również znajdujące się w kościele Świętojańskim. Jego kompozycja architektoniczna, z zamkniętym półkoliście polem środkowym ujętym kolumnami na konsolach flankujących kartuszowy fartuch, jest zbliżona do pomnika Frisiusa ${ }^{18}$. Na inną genezę wskazuje jednak rodzaj ornamentu architektonicznego, sposób i precyzja opracowania rzeźbiarskiego, a także - co szczególnie istotne - technika. Architektoniczna dekoracja epitafium Gretscha odwołuje się do przedserliańskich form typowych dla obszaru niemieckiego pierwszej połowy XVI wieku, zaczerpniętych zapewne z grafiki tzw. małych mistrzów, a pośrednio z modeli włoskich XV i początku XVI stulecia. Różni się więc od oszczędnych form charakteryzujących epitafium Frisiusa, reprezentujących późniejszą fazę stylową i odmienne chyba środowisko artystyczne. Trudno zakładać, iż ten sam mistrz - o raczej przeciętnych umiejętnościach - niemal jednocześnie posługiwał się dwoma wyraźnie odmiennymi modusami stylowymi. Za tezą tą przemawia też inna technika wykonania. W istocie, epitafium Gretscha nie jest dziełem kamieniarskim, bowiem jego struktura została wykonana z zaprawy murarskiej na metalowym rusztowaniu, zaś scena figuralna oraz pole herbowe w naczółku - z drewna ${ }^{19}$.

15 Polichromia była zazwyczaj wykonywana przez niezależny warsztat malarski już po ukończeniu prac rzeźbiarskich. Błędna jest informacja, jakoby kolumny wykonane były z czerwonego marmuru (DOMASŁOWSKI 2003, s. 173). O tym układzie barwnym najpełniej Michał WARDZYŃSKI, Między Italią a Niderlandami. Środkowoeuropejskie ośrodki kamieniarsko-rzeźbiarskie wobec tradycji nowożytnej. Uwagi z dziedziny materiałoznawstwa, [w:] Materiał rzeźby. Między techniką a semantyką, red. A. LIPIŃSKA, Wrocław 2009, s. 425-455.

16 Np. Georg CUNY, Danzigs Kunst und Kultur in 16. und 17. Jahrhundert, Frankfurt am Main 1910; o tym również Franciszek SKIBIŃSKI, Foreign architects, masons, stonecutters and sculptors in Gdańsk c. 1560-1630. Immigration, adaptation, expansion, [w:] Roving Renaissances. Migration of Architects and Architectural Exchange in Early Modern Europe (15th-17th centuries), ed. K. OTTENHEYM (w druku).

17 Walther HENTSCHEL, Dresdner Bildhauer des 16. und 17. Jahrhunderts, Weimar 1966.

18 DOMASŁOWSKI 2003, s. 173; KLUCZWAJD, TYLICKI 2009, s. 199.

19 Ze strukturą tego dzieła mogłem zapoznać się przy okazji prac restauratorskich prowadzonych w kościele świętojańskim przez firmę RESTAURO Sp. z o.o.; za pomoc chciałbym podziękować Izabelli Brzostowskiej. 
Obok samodzielnych obiektów rzeźbiarsko-kamieniarskich, takich jak epitafia, kamieniarka w nowożytnym Toruniu to przede wszystkim detal architektoniczny. Był on szczególnie bogato reprezentowany w rozbudowanym na początku XVII wieku ratuszu Starego Miasta. Jak wskazują znane jedynie z fragmentarycznych odpisów sprawozdania z posiedzeń rady miejskiej, zasadnicza część prac w ratuszu przeprowadzona została w latach 1602 $1605 / 1606^{20}$. W świetle przekazów źródłowych nie ulega wątpliwości to, iż kierował nimi mistrz Wilhelm (Willem) Mertens (Martens), zazwyczaj określany jako kamieniarz („Steinhauer") ${ }^{21}$. Mimo to jego pozycja i rola pozostają kwestią sporną. Wielu uczonych - przede wszystkim Jadwiga Habela - usiłowało pomniejszać rolę Mertensa, akcentując wkład projektodawcy, za którego uważano Anthonisa van Obberghen, architekta niderlandzkiego pochodzenia czynnego w Danii oraz w Gdańsku² ${ }^{22}$ Problem autorstwa projektu rozbudowy ratusza oczywiście wykracza poza ramy niniejszego przyczynku. Z punktu widzenia studiów nad kamiennym detalem architektonicznym, który ozdobił nowy gmach, bardziej istotny jest jednak właśnie Mertens i jego warsztat.

Nowe ustalenia dotyczące działalności tego mistrza prowadzą do przynajmniej częściowej rewizji dominującej w dotychczasowej literaturze krytycznej opinii o jego przygotowaniu zawodowym. Być może Niderlandczyk z pochodzenia, Mertens był czynny w Elblągu przynajmniej od roku 1583. Na ile można zorientować się z oryginalnych dokumentów oraz sumarycznych wypisów z autorstwa Wilhelma Behringa, pełnił on tam funkcję budowniczego miejskiego, co sugeruje fakt otrzymywania przezeń dość regularnych wypłat z elbląskiej kamlarii ${ }^{23}$. W chwili przybycia do Torunia był już więc uznanym budowniczym, z ponad

20 Eugeniusz GĄSIOROWSKI, Ratusz staromiejski w Toruniu, Toruń 2004, s. 91-132. Autor oparł się na dwóch niemalże identycznych egzemplarzach wypisów z akt posiedzeń rady, zachowanych w Archiwum Państwowym w Toruniu: Ex actis consularibus Thorunens. 1600-1638, Archiwum Państwowe w Toruniu, Kat. II, II, 4 oraz Ex actis consularibus memoranda, Archiwum Państwowe w Toruniu, Kat. II, II, 2.

21 Tak np. Ex actis consularibus memoranda, Archiwum Państwowe w Toruniu, Kat. II, II, 2, s. 23, 66-67.

22 Jadwiga HABELA, Problemy autorstwa związane z działalnością Antoniego van Obbergena na terenie Pomorza Wschodniego, „Kwartalnik Architektury i Urbanistyki”, t. 19, nr 1, 1974, s. 88-91. Rolę Obbergena podkreślali też Jadwiga PUCIATA-PAWŁOWSKA, Z dziejów stosunków artystycznych Torunia i Gdańska w XVI i XVII wieku, „Teka Komisji Historii Sztuki TNT”, t. 1, Toruń 1959, s. 150, 154-156; Sławomir SZCZERBIŃSKI, Antoni van Obberghen (1543-1611) budowniczy i architekt, [w:] Artyści w dawnym Toruniu, red. J. POKLEWSKI, Warszawa, Poznań 1985, s. 30-35; GĄSIOROWSKI 2004, s. 115-118 (za wcześniejszym studium tego autora też Stefan CACKOWSKI, Terytorium, ludność, władze miejskie, [w:] Historia Torunia, red. M. BISKUP, II/2, W czasach renesansu, reformacji i wczesnego baroku (1548-1660), Toruń 2004, s. 8-9). Inni zachowali jednak większą ostrożność, np. Michał WOŹNIAK, Ratusz staromiejski w Toruniu. Dzieje - architektura - adaptacja, [w:] Ratusz w miastach północnej Europy. Materiały konferencji - Gdańsk 23-25 XI 1993, red. S. LATOUR, Gdańsk 1997, s. 167-168 oraz KLUCZWAJD, TYLICKI 2009, s. 196, 200-201. Utrwaloną w literaturze wizję działalności Obberghena zdecydowanie i przekonująco zakwestionował Arnold Bartetzky, patrz: Arnold BARTETZKY, Das Grosse Zeughaus in Danzig. Baugeschichte. Architekturgeschichtliche Stellung. Repräsentative Funktion, Stuttgart 2000; Tenże, Anthonis van Obberghen, [w:] Die Baumeister der „Deutschen Renaissance”. Ein Mythos der Kunstgeschichte?, Hg. A. BARTETZKY, Leipzig 2004, s. 143-168; TENŻE, Anthonis van Obberghen and the Great Arsenal of Gdańsk, [w:] Netherlandish Artists in Gdańsk in the Times of Hans Vredeman de Vries. Conference - Gdańsk 20-21 XI 2003, Gdańsk 2006, s. 31-34.

23 Odnotowany w rachunkach miejskich w latach 1583, 1585, 1589 i 1591, patrz: Miasto Elbląg, Kamlaria, Archiwum Państwowe w Gdańsku, sygn. 369, 1/1389, s. 68, sygn. 369, 1/1390, s. 92 i sygn. 369, 1/1395, s. 179; także: Alphabetische Auszüge aus den Kämmerei-Rechnungen [1530-1709], Wilhelm Behring, Rękopisy elbląskie, Archiwum Państwowe w Gdańsku, sygn. 492/27, s. 25 oraz Fortlaufende Auszüge aus den Kämmerei-Rechnungen [1583-1629], Wilhelm Behring, Rękopisy elbląskie, Archiwum Państwowe w Gdańsku, sygn. 492/28b, s. 67, 113, 146. W dokumentach elbląskich - inaczej niż w toruńskich - Mertens określany jest jako „Maurer”. 
dwudziestoletnim doświadczeniem w prowadzeniu poważnych prac. Dzięki realizacjom w Elblągu i Toruniu - a może też w innych miejscach - Mertens zdobył zaufanie króla Zygmunta III Wazy. W latach 1614-1619 dostarczał on monarsze, zaangażowanemu w tym czasie m.in. w budowę zamku królewskiego w Warszawie, znacznych ilości kamienienia z Gotlandii oraz Niderlandów ${ }^{24}$. Surowy kamień lub gotowe elementy architektoniczne sprzedawał również w Gdańsku, co wywołało sprzeciw jednego z czołowych mistrzów miejscowego cechu, wspomnianego już Willema van der Meer ${ }^{25}$. Potomkowie Mertensa, Wilhelm Młodszy i Leonhard Mertens, czynni byli w Elblągu i Gdańsku przynajmniej do połowy XVII wieku ${ }^{26}$. Zakrojona na szeroką skalę działalność członków rodziny Mertens w Elblągu każe na nowo ocenić rangę tego ośrodka i jego oddziaływanie na terenie Prus, a nawet całej Rzeczpospolitej. W tym kontekście warto też przywołać innego architekta i rzeźbiarza związanego z tym miastem, mianowicie Wilhelma Pola (Pohla), czynnego też w Wielkim Księstwie Litewskim ${ }^{27}$.

W Toruniu warsztat kierowany przez Wilhelma Mertensa wykonał - dziś niestety w znacznym stopniu zniszczoną - dekorację ratusza, w tym frontowe ściany facjat, dekorowane m.in. lwimi maskami, a także narożne wieżyczki z rzeźbionymi w piaskowcu dekoracyjnymi konsolami, również figuralnymi ${ }^{28}$ (il. 4). Był on też odpowiedzialny za prace murarskie, w tym za nadbudowanie skrzydeł ratusza. Wykonawcy bogatego wyposażenia wnętrz, do którego należał m.in. kominek z czarnego „marmuru” i alabastru w Sali Senatu, pozostają nieznani, choć nie można wykluczyć, iż warsztat kierowany przez elbląskiego budowniczego mógł być odpowiedzialny przynajmniej za jego część.

By wykonać wszystkie te prace, poza murarzami i niewykwalifikowanymi robotnikami Mertens musiał zatrudniać kilku kamieniarzy zdolnych do wykonania detalu architektonicznego. Jak podaje Georg Cuny - za którym informację tę powtarzają m.in. Jadwiga Habela i Eugeniusz Gąsiorowski - jednym z nich był przybyły z Hanoweru kamieniarz Melchior Krimpe (Grimpe) ${ }^{29}$. Dalszych informacji o tej postaci dostarcza wpis w aktach

24 Władysław CZAPLIŃSKI, Przyczynki do dziejów mecenatu artystycznego Zygmunta III, [w:] Sarmatica Artistica. Księga pamiątkowa ku czci profesora Władysława Tomkiewicza, Warszawa 1968, s. 98-99; Ryszard SZMYDKI, Artystyczno-dyplomatyczne kontakty Zygmunta III Wazy z Niderlandami Południowymi, Lublin 2008, s. 213-225. Patrz też Auksė KALADŽINSKAITĖ, Nauji duomenys apie Liachovičiu pilies statybą, „Menotyra. Studies of Art”, t. 43, nr 2, 2006, s. 31-34, gdzie mowa o kontaktach między agentem Jana Karola Chodkiewicza a elbląskim rzemieślnikiem, „co kamień robi do murów Królewskiej Mości”.

25 Akta zastępcy prezydującego burmistrza, Archiwum Państwowe w Gdańsku, sygn. 300, 5/8, s. 73.

26 O tym szerzej Michał WARDZYŃSKI, Marmo bianco statuario z Carrary oraz inne importowane gatunki marmurów włoskich $w$ małej architekturze i rzeźbie na terenie dawnej Rzeczypospolitej od XVI do końca XVIII wieku, [w:] Rzeźba w Prusach Królewskich w XVI - XVIII w. Materiały konferencji - Gdańsk, 18-19 IX 2009, red. J. KRIEGSEISEN, w druku (dr. Michałowi Wardzyńskiemu chciałbym serdecznie podziękować za udostępnienie tego studium przed jego publikacją).

27 W kontrakcie z Januszem Radziwiłłem z 1611 r. określony jako „architekt elbląski”; patrz: Aistė PALIUŠYTĖ, Lina BALAIŠYTĖ, Wilhelmas Pollis: nauji architekto veiklos šaltiniai, „Menotyra. Studies of Art”, t. 43, r 2, 2006, s. 25-30.

28 WOŹNIAK 1997, s. 167.

29 Georg CUNY, Hieronimus und Antonius van Obbergen, „Mitteilungen des Westpreussischen Geschichtsvereins", Jh. 3, 1904, s. 55-56 (autor powołuje się na list od Rady Miasta Torunia z dnia 13 lipca 1604 r. w archiwum gdańskim); HABELA 1974, s. 90-91; GĄSIOROWSKI 2004, s. 117. Wg Cuny’ego, po zakończeniu prac przy ratuszu 
toruńskiego cechu murarzy z 1604 r., dokumentujący przyjęcie wielce szanownego kamieniarza Melchiora Krimpe w poczet członków organizacji ${ }^{30}$. Choć dokument ten nie wspomina o jego pracach przy rozbudowie ratusza, dowodzi on, iż Krimpe rzeczywiście przebywał w Toruniu w czasie ich trwania, będąc tu uznanym i szanowanym rzemieślnikiem. Jak podaje Cuny, po ich zakończeniu planował on przenieść się do Gdańska. Jakiekolwiek były jego plany, przerwała je rychła śmierć: w księdze ślubów kościoła mariackiego w Toruniu znajduje się informacja o tym, iż w 1606 r. Margaretha, wdowa po kamieniarzu Melcherze Krempe, wyszła za mąż za Adama von der Eiche ${ }^{31}$.

Należy podkreślić fakt, iż również von der Eiche określony został jako kamieniarz („Steinhauer”). Biorąc pod uwagę ówczesne zwyczaje, można podejrzewać, iż był on bliskim współpracownikiem zmarłego. Ta sama księga dostarcza kolejnej interesującej informacji: w 1605 r. ślub wziął tu inny kamieniarz, Jacob Hansen ${ }^{32}$. Przy tej okazji wymieniono również nazwisko Wilhelma Mertensa. Istnienia prywatnych związków pomiędzy Wilhelmem Mertensem, Melchiorem Krimpe, Adamem von der Eiche i Jacobem Hansenem sugeruje, iż mogli być oni powiązani ze sobą również na niwie zawodowej. Jako że - poza szczególnym przypadkiem Melchiora Krimpe - nie zostali oni odnotowani w aktach miejscowego cechu, może tu chodzić właśnie o członków kierowanej przez Mertensa grupy budowniczych i kamieniarzy, sprowadzonych przez radę miasta w celu rozbudowy staromiejskiego ratusza.

Jeśli hipoteza ta znajdzie potwierdzenie, oznaczałoby to, iż mistrz prowadzący prace w ratuszu zatrudniał pomocników spoza miasta, być może współpracujących z nim jeszcze w Elblągu ${ }^{33}$. Nie można jednak wykluczyć tego, iż w rozbudowę siedziby władz miejskich zaangażowani byli też rzemieślnicy miejscowi, zapewne członkowie toruńskiego cechu murarzy, na co według Eugeniusza Gąsiorowskiego wskazuje skala i szybkie tempo prac ${ }^{34}$. Organizacja ta była raczej niewielka i wyraźnie sprofilowana: w odróżnieniu od licznego i prężnego gdańskiego cechu murarzy, kamieniarzy i rzeźbiarzy, zatrudniała przede wszystkim murarzy. Wśród toruńskich mistrzów czynnych na przełomie XVI i XVII w. można wymienić Andreasa Wittiga, Adama Nagela - który wykształcił stosunkowo dużą liczbę uczniów - Paula Schubarta i Nicolasa Przykorę (?) ${ }^{35}$. Próżno szukać wśród nich przybyszów z odległych stron, którzy (zwłaszcza Niderlandczycy, ale też inni, jak Hans Kramer czy Hans

Krimpe miał przenieść się do Gdańska i wstąpić do tamtejszego cechu.

30 Księga protokołów mistrzów cechu murarskiego (1572-1821), Archiwum Państwowe w Toruniu, Kat. IV, Cech murarzy 3, s. 210; patrz też Stanisław HERBST, Toruńskie cechy rzemieślnicze. Zarys przeszłości, Toruń 1933, s. 190.

31 Liber Copulatorum 1600-1755, Parafia Wniebowzięcia Najświętszej Marii Panny w Toruniu, Archiwum Akt Dawnych Diecezji Toruńskiej, AD 001, s. 19.

32 TAMŻE, s. 17.

33 Patrz HERBST 1933, s. 183.

34 GĄSIOROWSKI 2004, s. 117.

35 Jedynym kamieniarzem wspomnianym w aktach cechu $\mathrm{z}$ tego czasu jest wspomniany już Melchior Krimpe; rzeźbiarzy nie odnotowano; patrz: Księga protokołów mistrzów cechu murarskiego (1572-1821), Archiwum Państwowe w Toruniu, Kat. IV, Cech murarzy 3 oraz Księga protokołów bractwa czeladniczego (1617-1710), Archiwum Państwowe w Toruniu, Kat. IV, Bractwo Czeladnicze Murarzy 3. O murarzach w Toruniu patrz też m.in.: Krzysztof MIKULSKI, Przestrzeń i społeczeństwo Torunia od końca XIV do początku XVIII wieku, Toruń 1999, s. 118-119, 283, 286. 
Schneider von Lindau) odegrali tak istotną rolę w Gdańsku. W mieście czynni byli rzemieślnicy, którzy przybyli z miejsc tradycyjnie związanych z Toruniem: Królewca, Gdańska, a szczególnie Śląska. Związki toruńskich mistrzów i czeladników z Gdańskiem, największym ośrodkiem kamieniarskim i rzeźbiarskim w regionie, są jednak zaskakująco trudno uchwytne. Również w gdańskim cechu pojawia się niewiele wzmianek o przybyszach z Torunia, w przeciwieństwie do tych z Elbląga bądź Królewca ${ }^{36}$. Jedna z nielicznych dotyczy czeladnika Reinholda Klercke, który - wedle słów gdańskich mistrzów - miał przez dwa lata poznawać tajniki rzemiosła w mieście nad Wisłą ${ }^{37}$.

W tej sytuacji nie dziwi to, iż torunianie pragnący zamówić epitafia bądź elementy detalu architektonicznego często zwracali się do rzeźbiarzy i kamieniarzy czynnych w innych ośrodkach, przede wszystkim w Gdańsku. Było to ułatwione dzięki istnieniu rozbudowanej sieci rodzinnych, ekonomicznych i politycznych powiązań pomiędzy toruńskimi patronami sztuki a ich gdańskimi odpowiednikami. Dla przykładu, pragnąc wypełnić testament ojca i upamiętnić swych przodków, a jednocześnie podkreślić w przestrzeni miejskiej rangę rodziny, przed 1590 rokiem burmistrz Henryk Stroband zlecił wykonanie epitafium swego ojca i dziada Willemowi van den Blocke, czołowemu rzeźbiarzowi czynnemu w tym czasie nad Motławą ${ }^{38}$. Ten pochodzący z Mechelen i wykształcony w Antwerpii artysta musiał być już wtedy znany jako twórca monumentalnych pomników księżnej Elżbiety w Królewcu (1578-1582) oraz Krzysztofa Batorego, brata króla Stefana, przeznaczonego wprawdzie do kościoła jezuitów w Alba Iulia w Siedmiogrodzie, lecz wykonanego w latach 1582-1583 w Gdańsku. Van den Blocke pracował również dla innych reprezentantów pruskich elit miejskich, rzeźbiąc m.in. epitafium gdańskiego burmistrza Johanna Brandesa.

Do gdańskich mistrzów zwracali się też inni toruńscy patrycjusze. Około 1600 roku członkowie rodziny Esken - być może Franz III Esken - zamówili w tamtejszym warsztacie portal i inne fragmenty detalu architektonicznego zdobiące należącą do nich kamienicę przy ulicy Łaziennej. Choć ustalenie autorstwa tego zespołu nie jest obecnie możliwe - o czym była mowa wcześniej - w przypadku portalu można wskazać na bliskie analogie we współczesnej kamieniarce gdańskiej, takie jak portal domu przy ul. Długiej 55 (dziś w Dworze św. Jerzego), czy też portal zdobiący ongiś fasadę dworu w Łapinie pod Gdańskiem, wyko-

36 Należy zrewidować informacje podane w: PUCIATA-PAWŁOWSKA 1959, s. 224-226. Wspomniany tam Paul von Thoren to zapewne Paul van Doren, pochodzący nie z Torunia, lecz z dalekiej Antwerpii (choć zapis jego nazwiska w wielu gdańskich źródłach może istotnie prowadzić do wniosku o jego toruńskim pochodzeniu); por. Janusz PAŁUBICKI, Rzeźba kamienna w Gdańsku w latach 1517 - 1585, „Gdańskie Studia Muzealne”, t. 3, 1981, s. 186. Natomiast wzmianka o Toruniu w kontrakcie zawartym przez gdańskiego mistrza Conrada Walthera w 1648 r. nie może prowadzić do wniosku, iż rzeźbiarz ten pracował w tym właśnie mieście; patrz pełny tekst kontraktu w: Juliusz STARZYŃSKI, Do dziejów polsko-gdańskich stosunków artystycznych w XVII wieku (przyczynek archiwalny), „Biuletyn Historii Sztuki i Kultury”, t. 2, nr 1, 1933, s. 67-70.

37 Akta cechów gdańskich, Archiwum Państwowe w Gdańsku, sygn. 300, C/2086, s. 80; przekaz ten dotyczy początku XVII w.

38 Atrybucję tę, opartą na formalnej analizie porównawczej, zaproponował po raz pierwszy Lech KRZYŻANOWSKI,Plastyka nagrobna Wilhelma van den Blocke, „Biuletyn Historii Sztuki”, t. 20, z. 3-4, 1958, s. 287; autor niniejszego studium przyjmuje ją również w rozprawie Willem van den Blocke. Netherlandish sculptor in the Baltic Region, [kps], Utrecht 2013, Universiteitsbibliotheek Utrecht. Na fragment testamentu Johanna Strobanda powołuje się - choć bez podania źródła - Artur SEMRAU, Die Grabdenkmäler der Marienkirche zu Thorn, „Mitteilungen des Coppernicus-Vereins für Wissenschaft und Kunst zu Thorn“, Jg. 7, 1892, s. 28. 
nany dla Adriana von der Linde w 1592 roku $^{39}$.

Innym, późniejszym przykładem związków z Gdańskiem są wykonane z piaskowca fragmenty portalu znajdującego się dziś w zachodniej elewacji budynku przy ul. Św. Ducha 1416 (il. 5). Choć był on dotąd uznawany za dzieło dziewiętnastowieczne, jego forma, materiał oraz technika wykonania sugerują znacznie wcześniejszą datę powstania ${ }^{40}$. Starsze elementy dekoracji architektonicznej zostały najprawdopodobniej wtórnie użyte w nowym budynku, wzniesionym w pierwszej połowie XIX wieku w miejscu wcześniejszych kamienic ${ }^{41}$. Obecny portal składa się zapewne z elementów dwóch różnych struktur ${ }^{42}$. W jego górnej części można dostrzec wpływ języka formalnego typowego dla Gdańska pierwszej połowy XVII stulecia, inspirowanego przede wszystkim twórczością Abrahama van den Blocke. Na tej podstawie można ją datować na drugą ćwierć, ewentualnie połowę XVII wieku Innymi przykładami kamiennego detalu architektonicznego wykazującymi bliskie związki z miastem nad Motławą są portale kamienic przy Starym Rynku 17 - należy zwrócić tu uwagę na rekonstruowany gdański portal dekorujący dziś fasadę domu przy ul. Ogarnej 99 - oraz przy ulicy Chełmińskiej 7 (il. 6, 7).

Pomimo roli, jaką odgrywał import z Gdańska, a może też wykształceni tam rzemieślnicy przybywający do Torunia w celu wykonania pojedynczych prac, kamienny detal architektoniczny powstawał też zapewne w warsztatach toruńskich. Przypuszczalnie na miejscu wykonywano np. kamienne elementy szczytów kamienic, choć nie można wykluczyć, iż również tego rodzaju obiekty sprowadzano z Gdańska bądź Elbląga. Możliwe też, że przynajmniej niektóre z mniejszych obiektów kamieniarskich zachowanych do dziś w Toruniu, takich jak dekoracja studzienki przy kościele świętojańskim, przechowywane w Muzeum Okręgowym elementy portali, czy wreszcie dekoracja furty w budynku dawnego klasztoru benedyktynek, zostały wykonane in situ ${ }^{43}$.

39 O tym drugim: Jerzy STANKIEWICZ, Nieznany zabytek renesansowej architektury Pomorza Gdańskiego, [w:] Komunikaty na sesję naukową poświęcona dziejom sztuki Pomorza. Materialy konferencji - Toruń 5-7 IX 1966, Toruń 1966, s. 88-93.

40 Datowanie takie podają autorzy dokumentacji konserwatorskiej kamienicy, patrz: Zbigniew NAWROCKI, Ewelina NAWROCKA, Toruń, budynki przy ul. Św. Ducha 14-16 / ul. Kopernika 28-30, Analiza historyczna w wytycznymi konserwatorskimi, [kps], Toruń 2010, s. 16, 22, Archiwum Miejskiego Konserwatora Zabytków, sygn. 4349. Zapewne z tego samego powodu obiekt ten pominęli też inni badacze, poczynając od Stanisława Dąbrowskiego (Stanisław DĄBROWSKI, Portale, bramy i sienie toruńskie XVII-go wieku, „Zapiski Towarzystwa Naukowego w Toruniu", t. 9, 1932-1934, s. 113-150), a kończąc na autorach niedawnej syntezy Dzieje sztuki Torunia (KLUCZWAJD, TYLICKI 2009).

41 Jak podają autorzy dokumentacji, w istniejącym budynku zachowane są relikty murów średniowiecznych - co widać też na elewacjach zewnętrznych - zaś do ok. 1900 r. istniały w nim nowożytne sklepienia piwnic (NAWROCKI, NAWROCKA 2010).

42 Do drugiego należy zapewne węższy blok kamienny w dolnej części obramienia po stronie prawej, z widocznym kanelowaniem oraz profilem gzymsu.

$43 \mathrm{~W}$ odniesieniu do portali należy wspomnieć o dwóch nadprożach z pocz. XVII w. w zbiorach Muzeum Okręgowego, bardzo zbliżonych do siebie pod względem dekoracji, choć znacznie różniących się jakością wykonania, patrz: Dokumentacja technologiczno-konserwatorska. Fragment nadproża, Zakład Konserwacji Elementów i Detali Architektonicznych, pod kier. Marii Rudy, Marii Zakrzewskiej, Marii Poksińskiej, [mps], Toruń, Biblioteka Muzeum Okręgowego w Toruniu, nr inw./sygn. S/656/MT oraz Dokumentacja konserwatorska: kamienne nadproże polichromowane, Zakład Konserwacji Elementów i Detali Architektonicznych, Joanna DUSZYŃSKA i Barbara GOLC pod kier. Marii Rudy i Daniela Kwiatkowskiego, [mps], Toruń 1987, Biblioteka Muzeum Okręgowego 
Obok omawianych dotąd dzieł fundowanych przez członków miejskich elit, do Torunia trafiły również obiekty zamawiane przez zleceniodawców spoza miasta. Należą do nich najbardziej monumentalne dzieła rzeźby kamiennej sprowadzone w tym czasie do Torunia, mianowicie pomniki braci Jakuba i Bartłomieja Tylickich oraz Anny Wazówny ${ }^{44}$.

Ten pierwszy, powstały prawdopodobnie około 1615 roku i ustawiony w kaplicy św. Róży w dominikańskim kościele pw. św. Mikołaja, składał się z dwóch figur zmarłych, sądząc po formie - analogicznych dzieł rzeźby sepulkralnej, ujętych w rozbudowaną strukturę architektoniczną ${ }^{45}$ (il. 8). Został on wykonany w małopolskich Chęcinach, na co wskazuje przede wszystkim zastosowany do odkucia figur zmarłych brązowy wapień, pochodzący z kamieniołomów położonych w pobliżu tej miejscowości ${ }^{46}$. Figury te wykazują daleko idące podobieństwo do szeregu dzieł rzeźby sepulkralnej w Wielkopolsce, Małopolsce, na Mazowszu i w Wielkim Księstwie Litewskim, takich jak pomniki Stanisława Krasińskiego w Płocku, Jana Ruszkowskiego w wielkopolskim Żerkowie czy Stanisława Przyjemskiego w Starym Mieście k. Konina - wszystkie z pierwszej ćwierci XVII wieku ${ }^{47}$ (il. 9). Były one dotąd przypisywane anonimowemu rzeźbiarzowi, nazywanemu w literaturze nieco niezgrabnie „Mistrzem wyprostowanych postaci”48. Ostatnio Michał Wardzyński wskazał, iż tym bardzo produktywnym artystą był najprawdopodobniej osiadły w Chęcinach Bartholomeo Venosta, przybyły do Rzeczpospolitej z Południowego Tyrolu ${ }^{49}$.

Szczegóły fundacji pomnika Tylickich pozostają nieznane. Jak twierdził - bez podania źródeł - Jakub Fankidejski, fundatorami kaplicy byli biskup krakowski Piotr Tylicki oraz jego brat Jakub, jedna z osób upamiętnionych w omawianym nagrobku ${ }^{50}$. Być może to wła-

w Toruniu, nr inw./sygn. S/655/MT. Być może istnieje warsztatowy związek pomiędzy świętojańską studzienką a drugim $z$ nadproży.

44 Można też wspomnieć o epitafium Adriana Dąbskiego, wykonanym prawdopodobnie z czarnego wapienia i alabastru, wzniesionym w kościele św. Mikołaja około 1651 r.; patrz: Epitaphia in Ecclesia Fratrum Ordin. Praedicatorum Thorunii [ok. 1740], Archiwum Państwowe w Toruniu, Kat. II, X-17, s. 8-9; Jakub FANKIDEJSKI, Utracone kościoły i kaplice $w$ dzisiejszej dyecezyi chełmińskiej podług urzędowych akt kościelnych, Pelplin 1880, s. 30-31; Władysław SZOŁDRSKI, Z dziejów dominikanów w Toruniu, „Zapiski Towarzystwa Naukowego w Toruniu”, t. 8, 1929-1931, s. 54.

45 „In Capella Scae Rosae parieti affixum, una cum duabus figuris marmoreis”, Epitaphia in Ecclesia Fratrum Ordin. Praedicatorum Thorunii (ok. 1740), Archiwum Państwowe w Toruniu, Kat. II, sygn. X-17, s. 7-8 (cyt. bez podania źródła w SEMRAU 1892, s. 35); patrz też SZOŁDRSKI 1929/1931, s. 53. Por.: KRZYSZTOFIAK 2005, s. 348-351.

46 Michał WARDZYŃSKI, Artifices chencinensis. Rola i miejsce warsztatów chęcińskich w produkcji kamieniarsko-rzeźbiarskiej w Rzeczpospolitej (koniec XVI - 1. połowa XVII wieku), [w:] Franciszka z Krasińskich Wettyn. Księżna Kurlandii i Semigalii, prababka dynastii królów włoskich. Dziedzictwo rodziny Krasińskich w regionie świętokrzyskim, red. D. KALINA, R. KUBICKI, M. WARDZYŃSKI, Kielce - Lisów 2012, s. 151-184.

47 TAMŻE, s. 159. Za błędną należy uznać hipotezę o gdańskim pochodzeniu figur (tak KRZYŻANOWSKI 1966, s. 138, za nim KRZYSZTOFIAK 2005, s. 352-356), której przeczą zarówno względy materiałowe, jak i formalne.

48 Np. Mariusz KARPOWICZ, Rzeźba około roku 1600-1630, [w:] Sztuka około 1600. Materiały konferencji Lublin 1972, Warszawa 1974, s. 72-73.

49 WARDZYŃSKI 2012, s. 157-161.

50 FANKIDEJSKI 1880, s. 30. Oprócz Bartłomieja i Jakuba Tylickich w kaplicy upamiętniono też Adama Tylickiego, syna Jakuba. W jego inskrypcji nagrobnej znalazło się odniesienie zarówno do Piotra, jak i Bartłomieja Tylickich; patrz: Szymon STAROWOLSKI, Monumenta Sarmatarum beatae aeternitati, officina viduae et haeredum Francisci Caesarij, Cracoviae 1655, s. 401 (korzystałem z egzemplarza UMK, sygn. Pol.7.III.1151); dostęp online: http:// kpbc.umk.pl/dlibra/docmetadata?id=27036\&from=\&dirids=1\&ver_id=\&lp=1\&QI= . 
śnie bliski związek biskupa Tylickiego z Małopolską sprawił, iż fundatorzy zwrócili się do warsztatu czynnego w odległych Chęcinach. Warto jednak zauważyć, iż w tym czasie także inni członkowie czołowych szlacheckich rodzin Prus Królewskich sięgali po warsztaty małopolskie, nawet pomimo gwałtownie rosnącej pozycji Gdańska. Drugim obok nagrobka Tylickich spektakularnym przykładem tej orientacji jest monumentalny pomnik biskupa Piotra Kostki, wzniesiony ok. 1595 r. w katedrze chełmińskiej w Chełmży. Został on wykonany przez czynnego w Małopolsce rzeźbiarza określanego w starszej literaturze jako „Mistrz nagrobka Prospera Provany”, a przez Katarzynę Mikocką-Rachubową identyfikowanego jako Giovanni da Simonis ${ }^{51}$.

W przypadku pomnika braci Tylickich mamy do czynienia z obiektem wykonanym dla pochodzących z Prus zleceniodawców przez warsztat czynny w sercu dawnej Rzeczpospolitej. Inna była relacja pomiędzy zleceniodawcą a wykonawcą w przypadku drugiego monumentalnego dzieła rzeźby sepulkralnej wzniesionego w Toruniu w omawianym okresie, mianowicie mauzoleum Anny Wazówny. Tym razem to zleceniodawca pochodził spoza Prus, podczas gdy warsztat - najprawdopodobniej z Gdańska. Przyjmuje się, iż fundatorem pomnika był bratanek zmarłej, król Władysław IV, choć sam sarkofag z figurą mógł powstać jeszcze za życia Zygmunta III ${ }^{52}$.

Warsztat, w którym wykonano pomnik, nie został dotąd zidentyfikowany; w literaturze pojawiają się sugestie zarówno o jego gdańskiej, jak i południowej proweniencji. W swym niedawnym studium Alicja Saar-Kozłowska słusznie wskazała na bliskie analogie pomiędzy wykonaną około 1636 roku architektoniczną obudową niszy z sarkofagiem a wyposażeniem wnętrza kaplicy Kołudzkich w katedrze gnieźnieńskiej, opowiadając się raczej za gdańskim pochodzeniem obu dzieł ${ }^{53}$. Wskazują na to również źródła pisane, a może też - choć kwestia ta pozostaje nierozstrzygnięta - zastosowany material ${ }^{54}$. W opublikowanej w 1649 roku biografii arcybiskupów gnieźnieńskich kanonik włocławski Stefan Damalewicz zawarł informację, iż „marmurowe” wyposażenie kaplicy fundowanej w Gnieźnie przez Szymona Kołudzkiego zostało wykonane właśnie w Gdańsku ${ }^{55}$. Choć więc atrybucja pomnika Anny

51 Katarzyna MIKOCKA-RACHUBOWA, Mistrz nagrobka Provany - rzeźbiarz krakowski przełomu XVI i XVII wieku, „Rocznik Historii Sztuki”, t. 20, 1994, s. 5-85.

52 SAAR-KOZŁOWSKA 1986.

53 Alicja SAAR-KOZŁOWSKA, Problem autorstwa wyposażenia architektoniczno - rzeźbiarskiego kaplicy Kołudzkich $w$ katedrze w Gnieźnie. Próba rozpoznania cech warsztatu, „Acta Universitatis Nicolai Copernici”, Zabytkoznawstwo i Konserwatorstwo, t. 38, 2010, s. 15-87.

54 Michał WARDZYŃSKI, Marmury i wapienie południowoniderlandzkie na ziemiach polskich od średniowiecza do 2. poł. XVIII w. Import i zastosowanie w małej architekturze i rzeźbie kamiennej, „Biuletyn Historii Sztuki”, t. 70, nr 3-4, 2008, s. 352; identyfikuje on użyty materiał jako wapień mozański, typowy dla ówczesnych warsztatów gdańskich. Piotr Niemcewicz widzi jednak w kaplicy Kołudzkich raczej wapień dębnicki (Piotr NIEMCEWICZ, Konserwacja wapienia dębnickiego, Toruń 2005, il. 16; również tegoż - nieznana autorowi - dokumentacja konserwatorska kamieniarskiego wyposażenia kaplicy z 1999 r.).

55 „Perillustris Ac Adm Rndus Dnus Simon Koludzki [...] in ornanda Capella, quam sibi elegit pro sua suorumq. sepultura, cura non deside allaborat, cui postes marmoreos per latomum Dantiscanum accomodari ordinavit, bona"; Stefan Damalewicz, Series Archiepiscoporum Gnesnensium, typis Petri Elert, Varsoviae 1649, s. 31 (korzystałem z egzemplarza w Archiwum Archidiecezjalnym w Gnieźnie, sygn. BP 1065). Informację tę pomija Piotr PAWŁOWSKI, Stefan Damalewicz jako prekursor historii sztuki w Polsce, „Studia Włocławskie”, t. 14, 2012, s. 511-529. 
Wazówny Wilhelmowi Richterowi pozostaje hipotetyczna, najprawdopodobniej mamy tu istotnie do czynienia $\mathrm{z}$ dziełem jednego z warsztatów czynnych nad Motławą w drugiej ćwierci XVII wieku.

Czy powyższy przegląd wybranych dzieł rzeźby kamiennej w Toruniu w późnym XVI i w pierwszej połowie XVII wieku pozwala na wyciagnięcie wniosków dotyczących pozycji miasta na artystycznej scenie ówczesnej Rzeczpospolitej? Uwagę zwraca przede wszystkim niejednolitość, a nawet pewna przypadkowość omawianych dzieł. Dotyczy ona szczególnie ich genezy, zarówno w odniesieniu do pochodzenia warsztatowego, jak i fundatorów. Niektóre z nich zostały wykonane w samym Toruniu przez miejscowych bądź przyjezdnych rzemieślników, inne zaś są importami, sprowadzonymi z różnych ośrodków rzeźbiarskich dawnej Rzeczpospolitej. Złożoność sytuacji pogłębia fakt, iż najbardziej monumentalne dzieła rzeźbiarskie powstały na zamówienie zleceniodawców spoza miasta.

Zgromadzony materiał sugeruje, iż w samym Toruniu nie było wówczas rozwiniętej produkcji rzeźby kamiennej, która zaspokajałaby lokalne zapotrzebowanie i przyciągała zleceniodawców spoza miasta. Tezę tę potwierdzają również wyniki kwerendy archiwalnej, wskazujące wprawdzie na obecność w mieście pewnej liczby murarzy, lecz bardzo niewielu kamieniarzy czy rzeźbiarzy. Nie jest to zaskakujące. Ośrodki rzeźbiarskie były zazwyczaj stosunkowo nieliczne, co wynikało przede wszystkim ze specyfiki procesu produkcji. Na niewielką liczbę i małą mobilność warsztatów rzeźbiarskich wpływały problemy z dostępem do odpowiednich materiałów i wykwalifikowanej siły roboczej, a także rodzaj ich klienteli. W konsekwencji popyt, szczególnie na rzeźbę monumentalną, taką jak nagrobki, zaspokajany był przez duże centra, które eksportowały swe wyroby na znaczne odległości, co było najwyraźniej bardziej opłacalne, niż przenoszenie całego warsztatu.

Oczywiście, w mniejszych ośrodkach, takich jak Toruń, obecni byli kamieniarze zdolni do wykonania detalu architektonicznego, zapewne blisko współpracujący z warsztatami murarskimi. W samym Toruniu przynajmniej czasowo byli też czynni rzeźbiarze wykonujący rzeźbę figuralną, na co wskazują dzieła anonimowego mistrza odpowiedzialnego za epitafium Caspara Frisiusa. Jednakże pragnąc zamówić bardziej monumentalne dzieła, zwłaszcza odkute w szlachetnych materiałach, zleceniodawcy zwracali się do mistrzów czynnych poza Toruniem. Podobnie było w przypadku zakrojonych na szeroką skalę robót budowlanych, którym towarzyszyły prace kamieniarskie, takie jak rozbudowa ratusza staromiejskiego, która najwyraźniej wykraczała poza możliwości miejscowych warsztatów.

W konsekwencji miasto znalazło się na skrzyżowaniu wpływów, docierających z dominujących ośrodków rzeźbiarskich ówczesnej Rzeczpospolitej. Z punktu widzenia Torunia najważniejszym nich był z pewnością Gdańsk, co wynikało z takich czynników, jak bliskie związki pomiędzy elitami obydwu miast, produktywność i ranga czynnych nad Motławą warsztatów, a także z kwestii praktycznych, np. stosunkowej łatwości transportu gotowych dzieł. Gdańskie wpływy w Toruniu odzwierciedlały znacznie szersze zjawisko, mianowicie gwałtowny wzrost pozycji tego miasta jako wielkiego centrum rzeźbiarskiego, który nastąpił w końcu XVI i w pierwszej połowie XVII w., m.in. w wyniku zakrojonej na szeroką skalę 
działalności Willema i Abrahama van den Blocke ${ }^{56}$.

Akcentując rolę Gdańska nie można jednak zapominać o innych ośrodkach. Z Elbląga sprowadzono mistrza, a może też niektórych jego pomocników, któremu powierzono przeprowadzenie najważniejszej miejskiej inwestycji budowlano-kamieniarskiej epoki. Pewną rolę odegrały też bardziej odległe centra, takie jak małopolskie Chęciny, gdzie powstał monumentalny pomnik braci Tylickich. W tym wypadku motywów stojących za wyborem należy jednak szukać poza miastem, w kręgu działalności członków rodziny Tylickich i -w szerszym kontekście - innych pruskich rodzin szlacheckich. Pozycja Torunia odzwierciedla więc sytuację panującą w tym czasie na terenie całej Rzeczpospolitej, gdzie warsztaty gdańskie rywalizowały o dochodowe i prestiżowe zlecenia z pracowniami małopolskimi na ogromnym obszarze, sięgającym od zachodniej Wielkopolski, poprzez Mazowsze, Prusy i Małopolskę, aż po odległe krańce Wielkiego Księstwa.

\section{综综综}

\section{Stone sculpture in Toruń c. 1580-1650. Between local production and import from leading centres of sculpture production in the old Commonwealth}

This paper explores stone sculpture in Torun in the period between c. 1580 and 1650. First of all, it introduces some hitherto unpublished works. One of them is a sandstone relief depicting Marcus Curtius, created on the spot in the last quarter of the sixteenth century. Another major piece introduced here is a recently cleaned portal on Św. Ducha Street, most likely imported from Gdansk in the mid-seventeenth century. Moreover, the present text offers new conclusions with regard to some better known works, such as epitaphs of Caspar Frisius and Andreas Gretch (both executed in the last quarter of the sixteenth century), as well as funeral monuments of the Tylicki brothers (c. 1610-1615) and princess Anna of Sweden (c. 1636), the latter two imported from Chęciny in Małopolska (Lesser Poland) and Gdansk respectively. Finally, it explores rebuilding of the Old Town Hall in the early seventeenth century, in particular by re-examining written sources pertaining to this remarkable undertaking. It discusses professional position of Wilhelm Mertens, builder and stonecutter supervising elevating and redecorating of the town hall, as well as some of his probable assistants, namely Melchior Krimpe, Adam von der Eiche and Jacob Hanssen.

The primary question addressed in this paper concerns relation between local production and import from major centres of sculpture production in the Polish-Lithuanian Commonwealth. Even though some stonecutters and sculptors were active in the city in the late sixteenth

56 O tym: Franciszek SKIBIŃSKI, The Expansion of Gdańsk and the Rise of Taste for Netherlandish Sculpture in the Polish - Lithuanian Commonwealth in the Sixteenth and Seventeenth Centuries, [w:] The Low Countries at the Crossroads. Netherlandish architecture as an export product in Early Modern Europe (1480-1680), eds. K. de JONGE, K. OTTENHEYM [w druku]. Patrz też np. WARDZYŃSKI 2008. 
and the first half of the seventeenth century, Torun lacked strong sculptural milieu. Therefore, patrons from this urban centre as well as members of the nobility relied on imports rather than on local production. Beyond a doubt, the leading role was played by Gdansk, with its swiftly developing sculpture industry. However, other centres, such as Elblag or even Checiny, the latter located in the southern part of the kingdom, were important as well. Thus, in the period in question Torun found itself at the crossroads of influences exerted by major centres of sculpture production in the old Commonwealth. As such, it perfectly exemplifies situation in the country in general, with workshops based in its southern and northern parts competing with each other for prestigious and profitable commissions. 


\section{SPIS ILUSTRACJI:}

1. Toruń, kościół pw. św. Jana Chrzciciela i św. Jana Ewangelisty, epitafium Caspara Frisiusa, warsztat nieznany, 1586 r., fot. F. Skibiński.

2. Toruń, relief z Markiem Kurcjuszem (zaginiony), warsztat nieznany, 4. ćw. XVI w., fot. ZKEiDA UMK.

3. Schwerin, kościół Mariacki, Robert Coppens, Zmartwychwstanie, nagrobek księcia Krzysztofa, 1. 1594-1596, fot. F. Skibiński.

4. Toruń, Ratusz Starego Miasta, dekoracja wieżyczek, Wilhelm Mertens z warsztatem, 1602-1606, fot. F. Skibiński.

5. Toruń, kamienica przy ul. Św. Ducha 14-16, portal, nieznany warsztat gdański (?), 2. ćw. / poł. XVII w., fot. F. Skibiński.

6. Toruń, kamienica przy Starym Rynku 17, portal, nieznany warsztat gdański (?), ok. poł. XVII w., fot. F. Skibiński.

7. Gdańsk, kamienica przy ul. Ogarnej 99, portal, nieznany warsztat gdański, ok. poł. XVII w., rekonstrukcja, fot. F. Skibiński.

8. Toruń, kościół pw. Wniebowzięcia NMP, figura Bartłomieja (?) Tylickiego (zm. 1609 r.), Bartholomeo Venosta z warsztatem (?), ok. 1615 r., fot. F. Skibiński.

9. Stare Miasto k. Konina, kościół par., figura Stanisława Przyjemskiego, Bartholomeo Venosta z warsztatem(?), przed 1618 r., fot. F. Skibiński. 


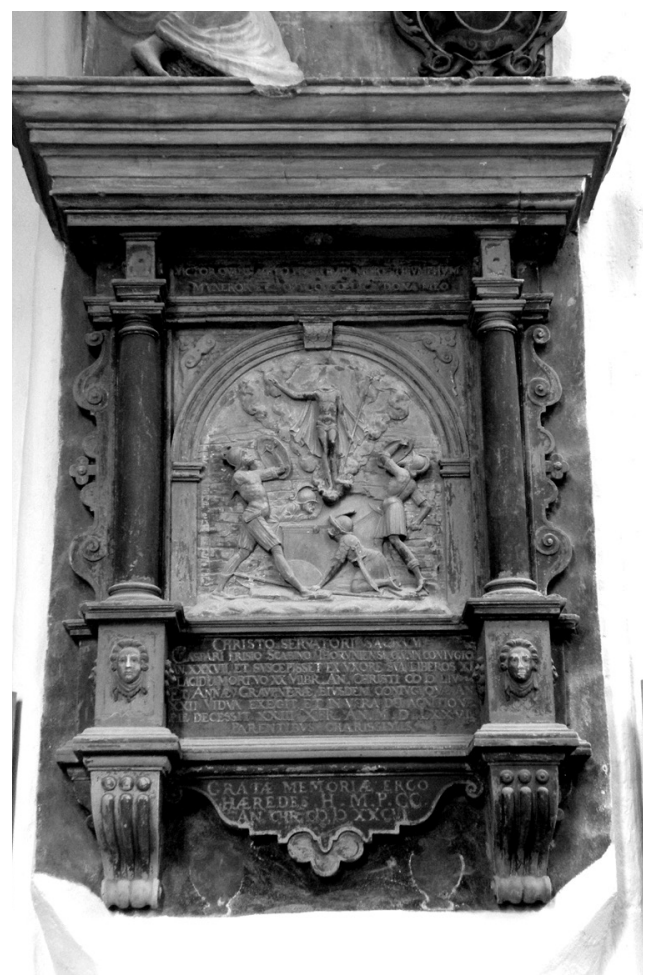

Il. 1 Toruń, kościół pw. św. Jana Chrzciciela i św. Jana Ewangelisty, epitafium Caspara Frisiusa, warsztat nieznany, 1586 r., fot. F. Skibiński

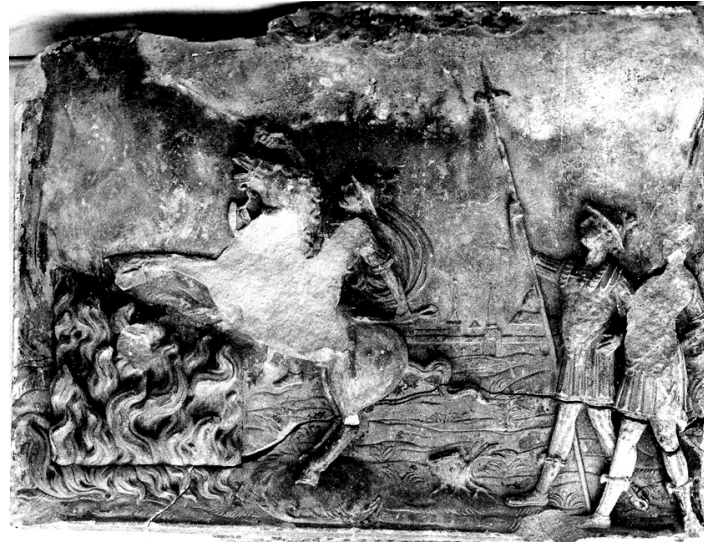

Il. 2 Toruń, relief z Markiem Kurcjuszem (zaginiony), warsztat nieznany, 4. ćw. XVI w., fot. ZKEiDA UMK

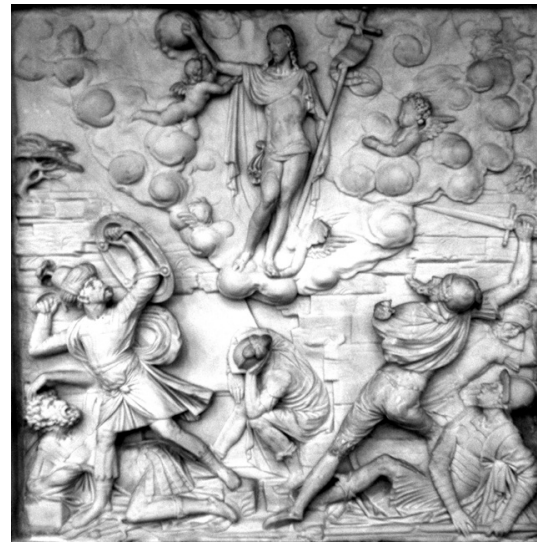

Il. 3 Schwerin, kościół Mariacki, Robert Coppens, Zmartwychwstanie, nagrobek księcia Krzysztofa, 1. 1594-1596, fot. F. Skibiński 


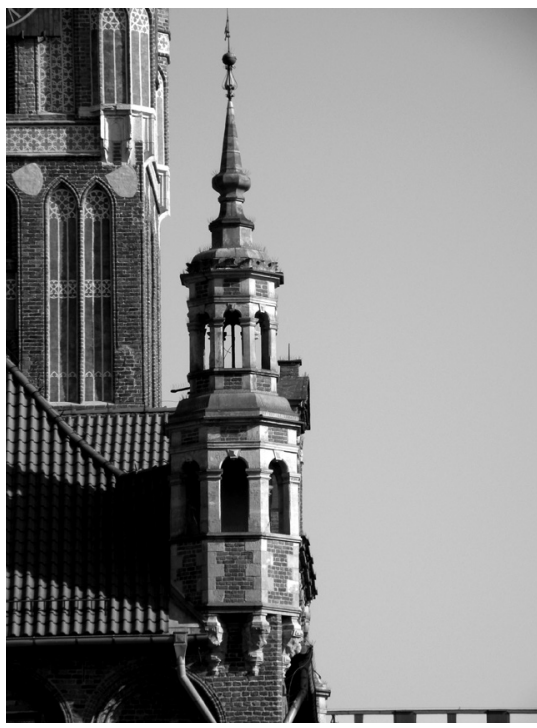

Il. 4 Toruń, Ratusz Starego Miasta, dekoracja wieżyczek, Wilhelm Mertens $\mathrm{z}$ warsztatem, 1602-1606, fot. F. Skibiński

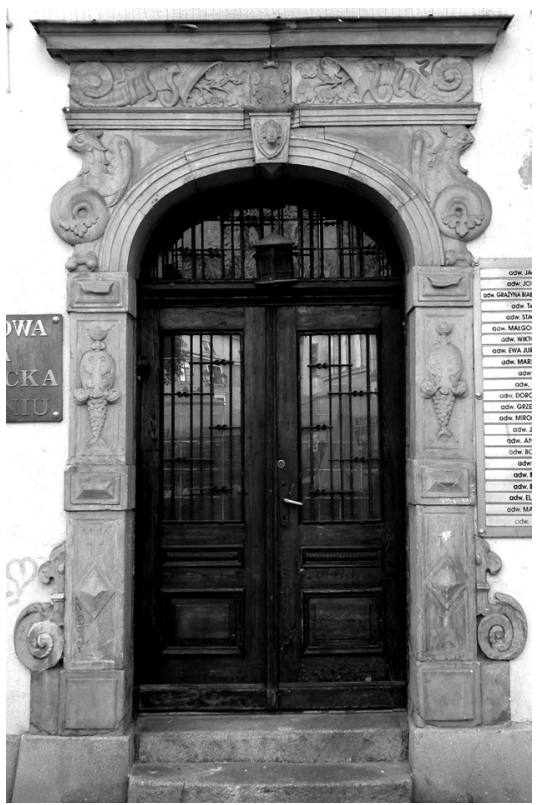

Il. 6 Toruń, kamienica przy Starym Rynku 17, portal, nieznany warsztat gdański (?), ok. poł. XVII w., fot. F. Skibiński

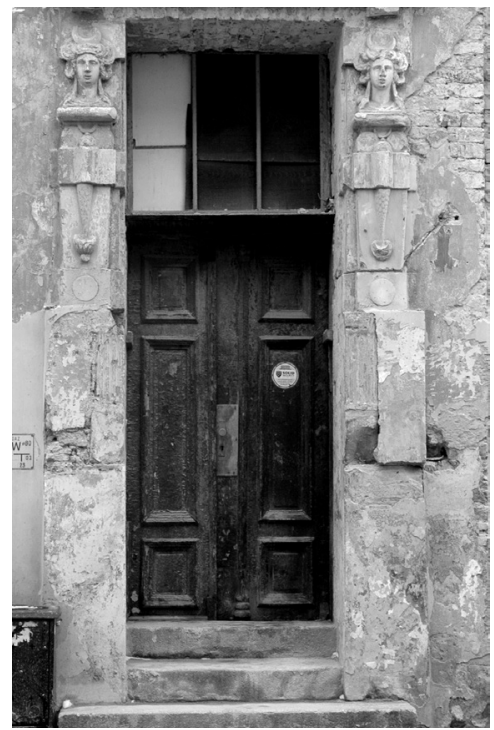

Il. 5 Toruń, kamienica przy ul. Św. Ducha 14-16, portal, nieznany warsztat gdański (?), 2. ćw. / poł. XVII w., fot. F. Skibiński

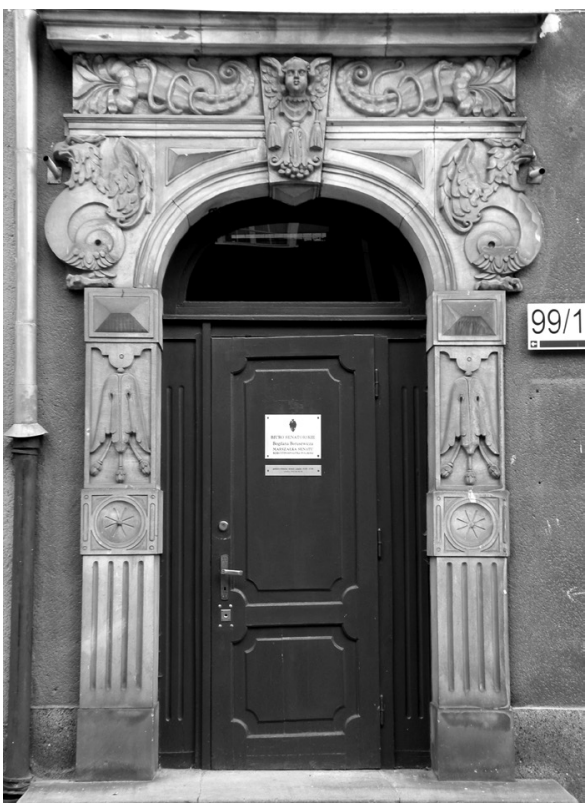

Il. 7 Gdańsk, kamienica przy ul. Ogarnej 99, portal, nieznany warsztat gdański, ok. poł. XVII w., rekonstrukcja, fot. F. Skibiński 


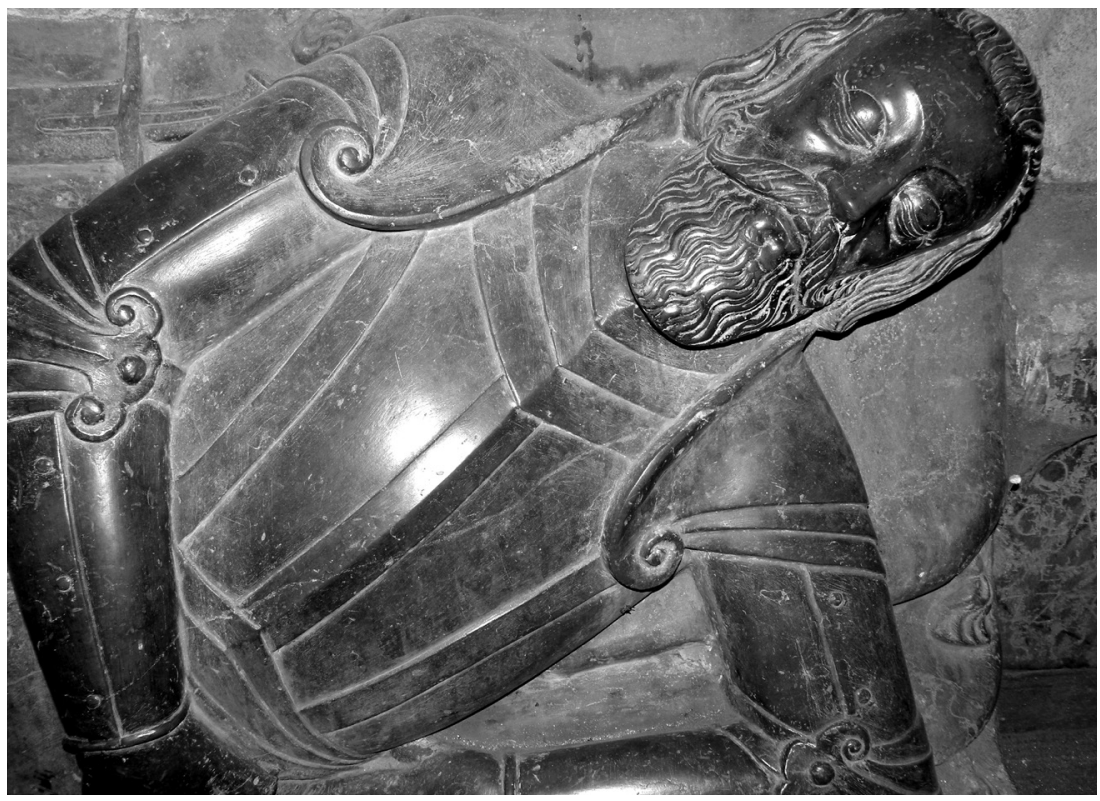

Il. 8 Toruń, kościół pw. Wniebowzięcia NMP, figura Bartłomieja (?) Tylickiego (zm. 1609 r.), Bartholomeo Venosta z warsztatem (?), ok. 1615 r., fot. F. Skibiński

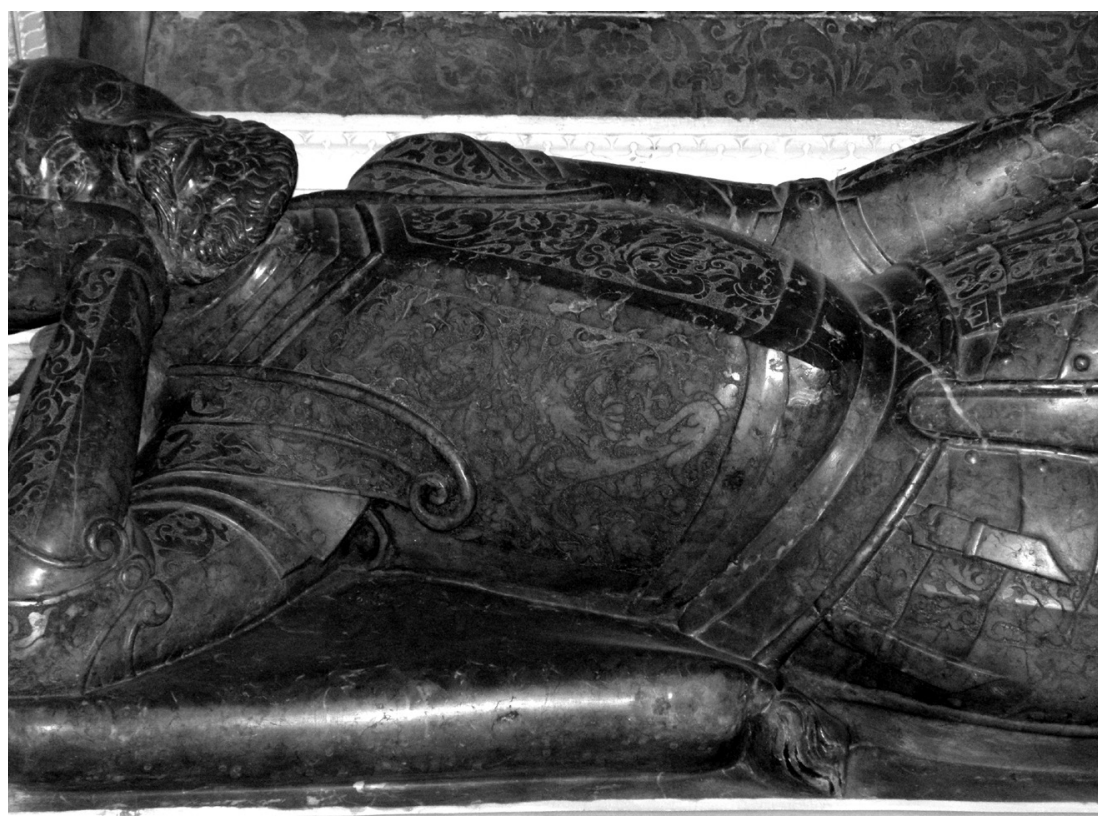

Il. 9 Stare Miasto k. Konina, kościół par., figura Stanisława Przyjemskiego, Bartholomeo Venosta z warsztatem(?), przed 1618 r., fot. F. Skibiński 